\section{Australian Journal of \\ Crop Science}

\title{
Performance of the Aquacrop model for bean (Phaseolus vulgaris L.) under irrigation condition
}

\author{
Ivomberg Dourado Magalhães ${ }^{1 *}$, Guilherme Bastos Lyra ${ }^{1}$, José Leonaldo de Souza ${ }^{1}$, lêdo Teodoro ${ }^{1}$, \\ Adolpho Emanuel Quintela da Rocha ${ }^{2}$, Constantino Antônio Cavalcante Júnior ${ }^{3}$, Gustavo Bastos Lyra ${ }^{4}$, \\ Ricardo Araújo Ferreira Junior ${ }^{1}$, André Luiz de Carvalho ${ }^{1}$, Rener Luciano de Souza Ferraz ${ }^{3}$
}

\author{
${ }^{1}$ Federal University of Alagoas (UFAL), Av. Lourival Melo Mota, s/n - Tabuleiro dos Martins, Maceió - AL - Brazil - \\ CEP: 57072-900 \\ ${ }^{2}$ Federal University of Viçosa (UFV), Av. Peter Henry Rolfs, s/n, Campus Universitário, Viçosa - MG - Brazil CEP: \\ 36570-900 \\ ${ }^{3}$ Federal University of Campina Grande (UFCG), Campina Grande -PB- Brazil- CEP: 58429-140 \\ ${ }^{4}$ Federal Rural University of Rio de Janeiro (UFRRJ), BR-465, Km 7, Seropédica - RJ - Brasil - CEP: 23897-000
}

\section{*Corresponding author: ivomberg31@hotmail.com}

\begin{abstract}
With the evident climatic threats and the limitation of agronomic information for the bean crop, the use of agricultural models is necessary to broaden and disseminate technical knowledge of crop forecasting. The aim of this work was to evaluate the FAO AquaCrop model for bean crop under different levels of irrigation water in agrometeorological conditions of Northeastern Brazil at megatheramal and humid climate. The research was conducted in the period from 11/17/2015 to 02/01/2016. The experimental design was randomized block with four replicates. Treatments were composed of six levels of irrigation on the basis of crop evapotranspiration (ETc) fractions $(25,50,75,100,125$ and $150 \%$ of ETc). The irrigation effect was evaluated from biomass, dry matter and grain yield data that were observed and simulated using Aquacrop model. One linear meter of plants was collected every 10 days for biometric and destructive analyses. In addition, the soil water content simulated from model was compared with measurements performed by time domain reflectometry. The AquaCrop model was calibrated for common bean during the dry season (October to March) for the region in the 2015/2016 harvest season using experimental data for $100 \%$ of ETc. The accuracy of the calibration and validation model was evaluated based on the root mean square error (RMSE), Willmott's index of agreement (d), correlation coefficient $(r)$ and percentage deviation (D). The model showed good performance between observed and simulated values for soil water content, dry biomass accumulation and grain yield in several water conditions and can assist decision making and water management in irrigated crops.
\end{abstract}

Keywords: Calibration; Evapotranspiration Phaseolus; Simulation; Validation.

Abbreviations: ETO_reference evapotranspiration; ETC_crop evapotranspiration; DAS_days after sowing; GY_Grain yield; HI_harvest index; SWC_soil water content; TDR_Time domain reflectometry; WP_water productivity;

Introduction

Common bean (Phaseolus vulgaris L.) is a crop of great importance for the Brazilian population, cultivated by farmers of different profiles at different scales, regions and production systems (Souza et al., 2016). Although this legume is considered a tropical crop with wide environmental adaptation, its productivity is still considered low (827 kg ha-1). The main causes for the low yield are the technologies used in cultivation and irregular meteorological factors. The low adoption of technologies, such as the inadequate use of irrigation and traditional cultivars with low productive potential, contributes to the reduced agricultural yield (CONAB, 2017).

Irregular use of water resources is one of the main factors limiting production. Thus, adequate water management, especially irrigation, is necessary to obtain maximum crop yield (Tamagi et al., 2016; Aamaas and Peters, 2017). It is emphasized that about $60 \%$ of the world's bean production are cultivated under conditions of water stress, either due to water excess or deficit in soil during the production cycle (CONAB, 2017). The effects of water stress are initially expressed in gas exchange alterations, which compromise production and translocation of photoassimilates and biomass accumulation, resulting in reduced productivity (Mathobo et al., 2017; Polón-Pérez et al., 2017).

Climate change and the small number of agronomic field trials have shown that the use of calibrated and validated mathematical models of crop forecasting can be useful to generate information about bean crop in future climatic scenarios. These models are used to study the effects and interactions of environmental conditions and can simulate scenarios under different soil and atmosphere conditions 
and assist irrigation planning and agricultural management (Homayununfar et al., 2014; Singh, 2014).

The FAO AquaCrop agrometeorological model (Raes et al., 2009) is ideal for simulation due to its easy calibration and few input requirements, maintaining a balance between simplicity, precision and robustness, compared to other models (Beletse et al., 2011; Bello et al., 2011; Mabhaudhi et al., 2014). AquaCrop is mainly focused on biomass simulation and crop yield in response to available water (Raes et al., 2009; Steduto et al., 2009; Abedinpour et al., 2012).

According to Ahmadi et al. (2015), since the AquaCrop model was released in January 2009, it has been able to simulate the yield and biomass of different crops under field conditions and soil water balance in various environmental conditions and irrigation regimes such as maize (Nyakudyaa and Stroosnijder 2014), cotton (Garcia-Vila et al., 2009), sunflower (Stricevic et al., 2011), wheat (Kumar et al., 2014), soybean (Khoshravesh et al., 2013), among others.

However, the Food and Agriculture Organization of the United Nations (FAO) growth and crop production model (AquaCrop) has been narrowly used for common bean. Therefore, obtaining technical-scientific information to support the crop development and promote increased productivity with competitive economic returns is essential. The aim of this work was to evaluate the FAO AquaCrop model for bean crop under levels of irrigation water from the agrometeorological conditions of Northeastern Brazil in megatheramal and humid climate.

\section{Results and Discussion}

\section{Weather conditions and soil water content}

During the bean crop cycle $(17 / 11 / 2015$ to $01 / 02 / 2016)$, total rainfall was $291.6 \mathrm{~mm}$, with irregular distribution. Thus, mean per rain event of $3.8 \mathrm{~mm}$ and frequency of approximately 1 event every 2.2 days were observed, corresponding to $45.4 \%$ of days with precipitation (Magalhães et al. (2017).

Figure 1 shows simulation results for SWC $(0-30 \mathrm{~cm})$ of common bean crop in the region of Rio Largo-AL. The simulated values, as well as those measured in the field, corresponded to the water supply in the soil (irrigation and precipitation) of treatments with 25 and $50 \%$ of ETc. It was also observed that there was an underestimation in the period between $10^{\circ}$ and $35^{\circ} \mathrm{C}$, when flowering began, except for the 75,100 and $125 \%$ of ETc, in which the model overestimated the simulated results during the forty days of observation. These values corroborate those found by Hsiao et al. (2009), Farahani et al. (2009) and Zeleke et al. (2011), who reported that the AquaCrop model tends to overestimate SWC for maize, cotton and canola crops, respectively. In contrast, other studies have shown that the AquaCrop model underestimated SWC for maize (Mebane et al., 2013; Biazin and Stroosnijder, 2012) and wheat crops (Iqbal et al., 2014; Mkhabela and Bullock, 2012).

According to Ahmadi et al. (2015), one of the main reasons for this variation of results is the model's failure in considering the great soil heterogeneity in the field. Therefore, using the same physical set of soil and water data is a potential source of substantial uncertainty in the SWC modeling. According to Gervais et al. (2010), the underestimation of $\mathrm{W}$ with high soil water contents by AquaCrop is probably caused by the model that does not allow soil water content to remain above field capacity (FC) for consecutive days. Raes et al. (2011), reported that AquaCrop model predicts saturated soils drain to reach FC in a short period of time. The same authors also reported that the AquaCrop model does not have a mechanism to deal with the sudden inflow of water into the system, i.e., a capillary ascension sub-routine has not yet been implemented.

Considering the crop cycle, it was observed that in plots irrigated with 25 and $20 \%$ of ETc, the soil water content remained 29.9 and $12 \%$ (observed values) below readily available water (RAW), respectively. These characterized water stress in treatments and the observed soil water content remained above RAW in areas irrigated with 100, 125 and $150 \%$ of ETc. The AquaCrop model has accurately predicted the application cycles and evaporation of soil water due to irrigation events, but tended to underestimate the SWC, particularly in irrigation-deficient plots (Farahani et al., 2009; Hussein et al., 2011; Paredes and Torres, 2016). Geerts et al. (2009) reported that when the soil water content simulation is accurately predicted, the crop evapotranspiration estimate is satisfactory for the soil water balance using the AquaCrop model.

The model performance statistics showed high agreement simulations $(0.97<" d "<0.99)$ in plots irrigated with the 25 , $50,75,100,125$, and $150 \%$ of Etc, when compared to observed values (Figure 1). The correlation was strong in all treatments $(25,50,75,100,125$ and $150 \%$ of ETC) with 0.61 $\leq \mathrm{r} \leq 0.75$. RMSE ranged from 8 to $17 \mathrm{~mm}$, corresponding to 8.1 to $12 \%$ of the total soil water storage.

\section{Dry biomass and grain yield}

The experimentally obtained and simulated biomass accumulation by the AquaCrop model along with crop cycle are presented in Figure 2. The model calibration was carried out with data from bean crop irrigated with $100 \%$ of ETC, since for this amount of irrigation, water requirements were adequately supplied, with no water stress due to water deficit or excess water (Magalhães et al., 2017). According to Andarzian et al. (2011), these factors are fundamental for the model parameterization. Data from the other treatments $(25,50,75,125$ and $150 \%$ of ETc) were used in the validation stage of the model in relation to biomass (Table 4). The model reached final biomass production in all irrigation depths.

The model presented biomass underestimation of $2 \%$ from the R5 phase (beginning of flowering), with irrigation depth corresponding to $25 \%$ ETc. The AquaCrop model overestimated biomass accumulation for the other irrigation depths $(50,75,100,125$ and $150 \%$ of ETc) in the development stages of the bean crop between the emergence of primary leaves (V2) and filling of pods (R8). However, between R8 and R9 (physiological maturation), simulated and observed values showed average variation of $5.6 \%$ for biomass, with no significant differences for evaluated data.

The greatest difference between experimental and simulated data was $19 \%$ which observed in treatments irrigated with $25 \%$. The lowest difference was $0.75 \%$ and 
Table 1. Soil physical and water characteristics in the experimental area in Rio Largo - Alagoas.

\begin{tabular}{llllll}
\hline Soil texture & Soil layers $(\mathrm{cm})$ & $\begin{array}{l}\text { Soil Density } \\
\left(\mathrm{g} \mathrm{cm}^{-3}\right)\end{array}$ & $\begin{array}{l}\text { Volumetric soil water content } \\
\left(\mathrm{mm} \mathrm{mm}^{-1}\right)\end{array}$ \\
\hline \multirow{3}{*}{ Middle clay } & & PWP & FC & SAT \\
& $0-10$ & 1.36 & 0.12 & 0.20 & 0.40 \\
& $10-20$ & 1.44 & 0.13 & 0.22 & 0.43 \\
\hline
\end{tabular}

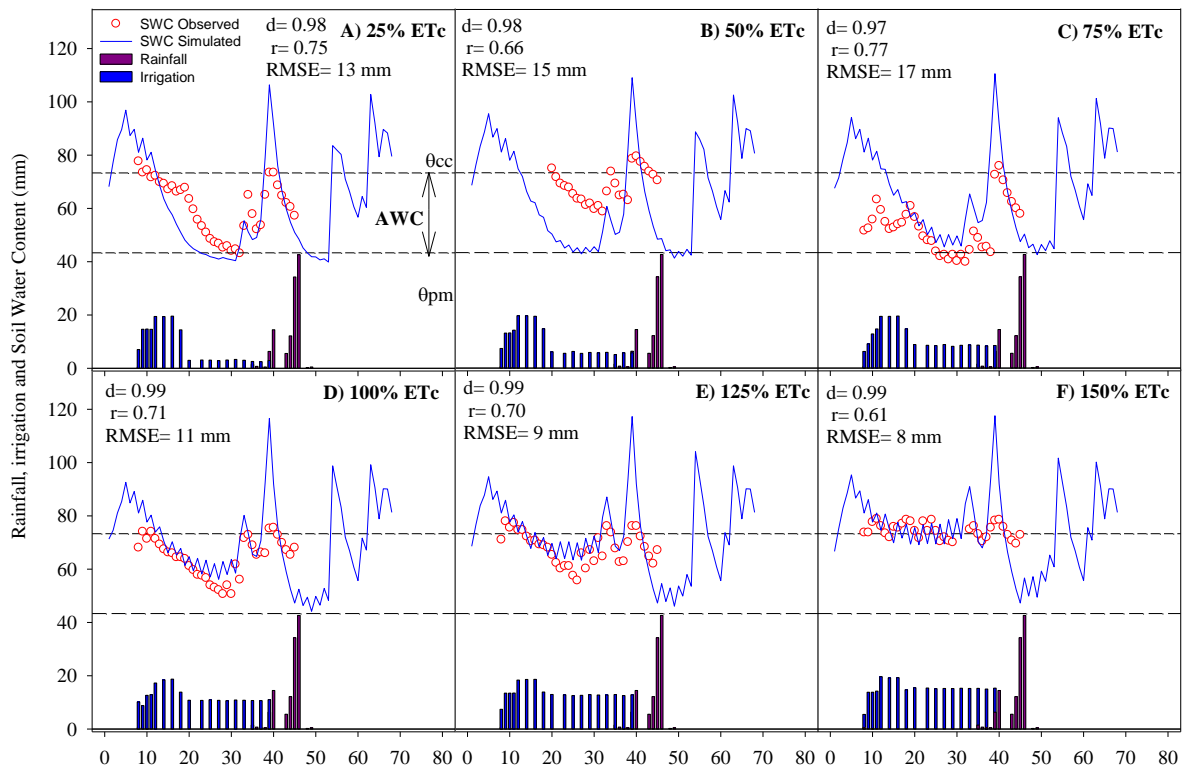

DAS

Fig 1. Soil water content in the root zone (SWC, mm), observed and simulated in the $0.0-0.30 \mathrm{~m}$ layer, with emphasis on the available water capacity (AWC, mm) for bean crop. Rio Largo - Alagoas.

Table 2. Period, in days, for each bean crop development stage.

\begin{tabular}{lllll}
\hline Phase/ Period & Initial & Development & Intermediate & Final \\
\hline Beginning of phase & $17 / 11 / 2015$ & $07 / 12 / 2015$ & $30 / 12 / 2015$ & $25 / 01 / 2016$ \\
Period (days) & 20 & 23 & 25 & $\ldots$ \\
\hline
\end{tabular}

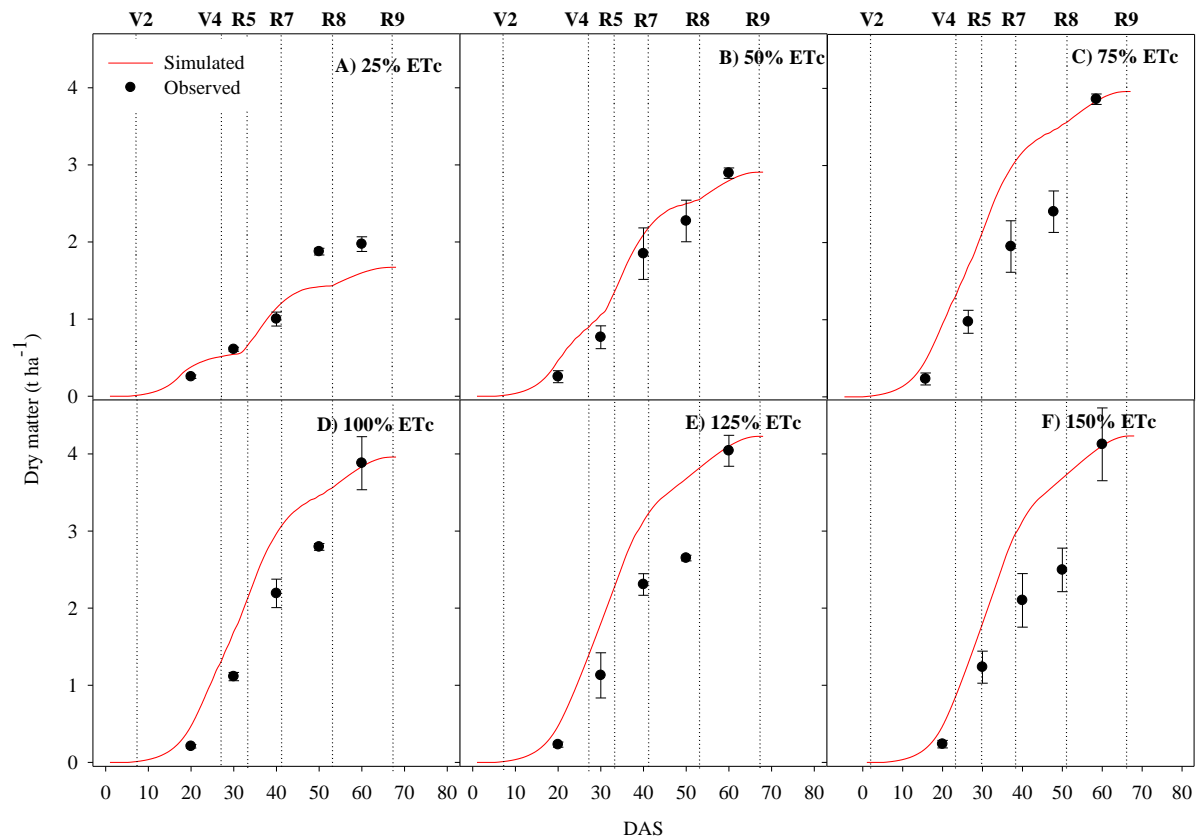

Fig 2. Observed and simulated dry matter (t ha-1) for common bean submitted to irrigation levels. V0 Germination; V1 Emergence; V2 Primary leaves; V3 First trifoliate leaf; V4 Third trifoliate leaf; R5 Pre-flowering; R6 Flowering; R7 Formation of pods; R8 Filling of pods; R9 Physiological maturation. Rio Largo - Alagoas. 
Table 3. Descriptions of conservative and input data of bean crop used in the AquaCrop model in the region of Rio Largo -Alagoas.

\begin{tabular}{|c|c|c|c|}
\hline Description of conservative parameters & Value & \multicolumn{2}{|l|}{ Unit } \\
\hline Base temperature ${ }^{1}$ & 10 & \multicolumn{2}{|l|}{${ }^{\circ} \mathrm{C}$} \\
\hline Maximum temperature & 30 & \multicolumn{2}{|l|}{${ }^{\circ} \mathrm{C}$} \\
\hline Soil $\mathrm{H}_{2} \mathrm{O}$ depletion factor, canopy expansion & 0.15 & \multicolumn{2}{|c|}{ Upper limit (p-exp) * } \\
\hline Soil $\mathrm{H}_{2} \mathrm{O}$ depletion factor, canopy expansion & 0.65 & \multicolumn{2}{|c|}{ Lower limit (p-exp) * } \\
\hline Positive impact coefficient in $\mathrm{HI}$ & 10 & \multicolumn{2}{|c|}{ Vegetative growth } \\
\hline Negative impact coefficient in $\mathrm{HI}$ & 8 & \multicolumn{2}{|c|}{ Stomatal closure } \\
\hline Maximum allowable increase of specified $\mathrm{HI}$ & 15 & \multicolumn{2}{|c|}{$\%$} \\
\hline Standard $\mathrm{H}_{2} \mathrm{O}$ production for $\mathrm{ET}_{0}$ and $\mathrm{CO}_{2}$ & 15 & \multicolumn{2}{|l|}{$\mathrm{gm}^{-3}(\mathrm{WP})$} \\
\hline $\begin{array}{l}\text { Standard } \mathrm{H}_{2} \mathrm{O} \text { production for } \mathrm{ET}_{0} \text { and } \mathrm{CO}_{2} \text { during yield } \\
\text { formation }\end{array}$ & 60 & \multicolumn{2}{|l|}{$\mathrm{gm}^{-3}(\mathrm{WP})$} \\
\hline \multirow{2}{*}{ Description of input variables } & \multicolumn{3}{|c|}{ Values } \\
\hline & Standad & Calibrated & Units \\
\hline Canopy coverage after sowing with $90 \%$ emergence $\left(C_{0}\right)$ & 5 & 5 & $\mathrm{~cm}^{2} /$ plant \\
\hline Canopy growth coefficient (CGC) & 11 & 23.8 & $\%$ day $^{-1}$ \\
\hline Canopy coefficient decline (CGC) up to senescence & 3 & 15.5 & $\%$ day $^{-1}$ \\
\hline Effective maximum root depth & 2 & 0.3 & $\mathrm{~m}$ \\
\hline Water yield & 15 & 15 & $\mathrm{~g} \mathrm{~m}^{-2}$ \\
\hline Sowing time up to emergence & 9 & 5 & $\mathrm{~d}$ \\
\hline Time from sowing to the beginning of flowering & 71 & 34 & d \\
\hline Time from sowing to the beginning of senescence & 104 & 54 & $d$ \\
\hline Time from sowing to maturity & 130 & 68 & d \\
\hline Flowering duration & 29 & 8 & d \\
\hline Number of plants & 330000 & 250000 & $\begin{array}{l}\text { plants ha- } \\
1\end{array}$ \\
\hline Average harvest index (HI) & 40 & 58 & $\%$ \\
\hline
\end{tabular}

* Limit soil water consumption to canopy expansion (Darko et al., 2016)

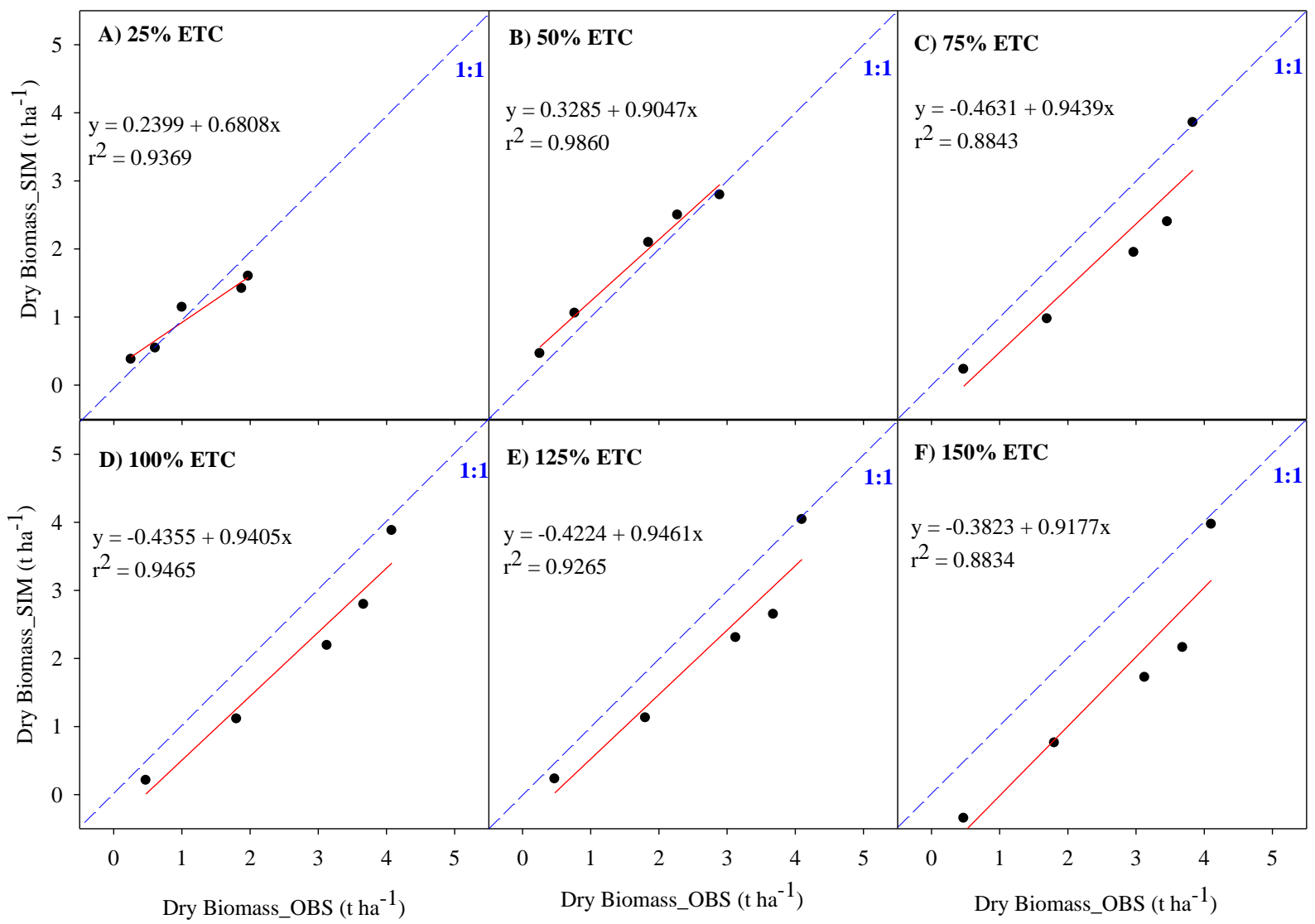

Fig 3. Regression analysis for observed (OBS) and simulated (SIM) accumulated dry biomass for bean crop submitted to irrigation levels. Rio Largo - Alagoas. 
Table 4. Comparison between observed and simulated values of dry biomass and grain yeld for calibration and validation of the FAO AquaCrop model for bean crop submitted to irrigation levels. Rio Largo - Alagoas.

\begin{tabular}{|c|c|c|c|c|c|c|c|c|c|}
\hline \multicolumn{6}{|c|}{ Dry Biomass (t ha ${ }^{-1}$ ) } & \multicolumn{4}{|c|}{ Grain yield $\left(\mathrm{t} \mathrm{ha}{ }^{-1}\right)$} \\
\hline $\begin{array}{l}\text { Irrigation } \\
\text { Levels }\end{array}$ & Obs & Sim & $\mathrm{D} \%$ & RMSE & $d$ & $r$ & Obs & Sim & $\mathrm{D} \%$ \\
\hline \multicolumn{10}{|l|}{ (Calibration) } \\
\hline $\begin{array}{l}\text { 100\% ETc } \\
\text { (Validation) }\end{array}$ & 3.88 & 4.08 & 5.14 & 0.67 & 0.94 & 0.97 & 2.10 & 2.42 & 15.54 \\
\hline $25 \%$ ETc & 1.97 & 1.60 & -18.88 & 0.28 & 0.92 & 0.92 & 1.35 & 0.94 & -30.42 \\
\hline $50 \%$ ETc & 2.89 & 2.80 & -3.39 & 0.22 & 0.99 & 0.99 & 1.64 & 1.65 & 0.43 \\
\hline $75 \%$ ETc & 3.86 & 3.83 & -0.65 & 0.74 & 0.91 & 0.94 & 1.95 & 2.35 & 20.68 \\
\hline $125 \%$ ETc & 4.04 & 4.10 & 1.44 & 1.15 & 0.94 & 0.96 & 2.23 & 2.44 & 9.60 \\
\hline $150 \%$ ETc & 4.12 & 4.10 & -0.50 & 1.05 & 0.92 & 0.94 & 1.89 & 2.45 & 29.63 \\
\hline
\end{tabular}

Treat - Treatments; Obs - Observed; Sim - Simulated; D\% - Percentage deviation; RMSE - Root mean square error (t ha-1 ${ }^{-1}$; $d$ - Willmot's of agrrement index; $r$ - correlation coefficient.

occurred in treatments irrigated with $75 \%$ of ETc. Paredes and Torres (2017) found similar trends when evaluated the parameterization of the AquaCrop model for pea biomass. In treatments with 50 to $150 \%$ of ETc, the model overestimated the dry biomass in all evaluations during the bean crop cycle, with the highest dispersions during 30,40 and 50 DAS.

Evaluation of last three points (40,50 and 60 DAS) after irrigation with $50 \%$ of Etc showed good concordance among observed values, which varied from $1.85,2.27$ to $2.89 \mathrm{t} \mathrm{ha}^{-1}$. The values simulated by the AquaCrop model were 2.10, 2.50 and $2.80 \mathrm{t} \mathrm{ha}^{-1}$, representing percentage variation of $13.37,9.90$ and $-3.39 \%$ for the three respective evaluations (40, 50 and 60 DAS). Similar results were found by Salemi et al. (2011) and Du et al. (2011) with wheat crop, observing increases in biomass accumulation as a function of the elevation of rainfall indexes in different regions and years of study. The $75 \%$ of ETc was underestimated for the total dry biomass accumulation in relation to the deviation percentage of $0.65 \%$, which represented; therefore, high correlation between simulated and observed values.

For 100 and $125 \%$ of ETc, the model overestimates the dry biomass accumulation values, which is due to the increment of the water content in the system, resulting in the total biomass overestimation. At 60 DAS, the values observed in field were 3.88 and $4.04 \mathrm{t} \mathrm{ha}^{-1}$, for the two respective levels, while simulations generated by the AquaCrop model were 4.08 and $4.10 \mathrm{t}$ ha-1, resulting in mean deviation percentages of 5.14 and $1.44 \%$ for 100 and $125 \%$ of ETc, respectively. The use of $100 \%$ of ETc is justified because water is a limiting factor for crop development, overcoming the radiation availability for the study region (Monteith, 1977).

The $150 \%$ of ETc presented lower variation of the mean deviation percentage when compared to the other five levels. In this case, the simulated data was underestimated by $0.50 \%$, compared to observed, demonstrating high concordance between values measured in the field and those simulated by the model in potential water conditions. According to Steduto et al. (2007), the model is based on the conservative behavior of WP, which is the relationship between biomass production and transpiration. In this study, as there was no water restriction, transpiration decreased and biomass accumulation increased.

The simulated and observed total biomass accumulation and grain yield values were submitted to statistical tests to calibrate and assess the validity of the AquaCrop model for bean crop submitted to six irrigation levels considering the crop evapotranspiration in the region of Rio Largo, AL (Table 4).

Comparison of total simulated with total oserved biomass showed average deviation of 5\%, representing high concordance among results, with values varying from -18.9 to 5.1. These results corroborate with Biazin and Stroosnijder (2012), who reported positive deviations of up to $17.7 \%$ for final biomass, while Hsiao et al. (2009) obtained deviations ranging from $-20.6 \%$ to $21.9 \%$. According to Marin (2014), a source of uncertainties related to the calibration process is that the values of parameters required by the model are usually modified from suggested reference values in the model distribution, or from literature or even from previous studies with the same model conducted not always under the same contour conditions.

Analysis of biomass accumulation in the six irrigation treatments showed minimum difference of variation in plots irrigated with $150 \%$ of ETc with $-0.50 \%$ and maximum irrigation with $25 \%$ of ETC $(-18.88 \%)$, indicating high sensitivity of the model to the water conditions of the study region, plus being correlated with variations in water levels. Araya et al. (2010) evaluated the performance of the AquaCrop model and found maximum deviation for biomass of $8.5 \%$ similar to that observed in the present study. However, there were underestimates of 18.9, 3.4, 0.6 and $0.5 \%$ in areas irrigated with $25,50,75$ and $150 \%$ of ETc, respectively. According to Hsiao et al. (2009), underestimation of biomass accumulation may have occurred due to the low input values for standardized water productivity and crop coefficient.

RMSE values ranged from 0.22 to $1.15 \mathrm{t} \mathrm{ha}^{-1}$ for treatments irrigated with 50 and $125 \%$ of ETc. Heng et al. (2009) analyzed simulated biomass accumulation and obtained RMSE between 0.46 and $6.51 \mathrm{t} \mathrm{ha}^{-1}$ for maize using the AquaCrop model. The Willmott's concordance index (d) ranged from 0.91 ( $75 \%$ of ETc) to 0.99 (50\% of ETc), verifying the concordance between data observed in the field and those simulated by the AquaCrop model. This indicates almost perfect accuracy, as it approached the ideal value (1.0). The Pearson's correlation coefficient ( $r$ ) presented excellent results when associated with irrigation levels. It shows high correlation between observed and simulated biomass accumulation data, ranging from 0.92 (150\% of ETc) to 0.99 ( $50 \%$ of ETc). For presenting correlation values, Vila 
et al. (2009) indicate the use of the AquaCrop model to optimize the deficit irrigation and to increase the biomass accumulation in cotton crop.

The greatest mean deviation fluctuations were observed in areas irrigated with 25 and $150 \%$ of ETc due to the presence of extremes water deficit and excess, limiting the simulation performance of the AquaCrop model, with underestimation of $30.4 \%$ and overestimation of $29.6 \%$ in the respective treatments. Water depths corresponding to 50, 100 and $125 \%$ of ETc presented mean deviation percentage between simulated and observed values of $0.4,15.5$ and 9.6\%, respectively. These results are ratified by Biazin and Stroosnijder (2012), who reported $11.8 \%$ deviation for the final grain yield, studying water conservation. The regression analyses of simulated and observed biomass accumulation of the six irrigation levels applied in bean crop are graphically represented in Figure 3 . The determination coefficients $\left(\mathrm{r}^{2}\right)$ were $0.94,0.99,0.88,0.95,0.93$ and 0.89 in treatments irrigated with $25,50,75,100,125$ and $150 \%$ of Etc, respectively, showing good results, since it corresponds to $100 \%$ effect of treatments. Mabhaudhi et al. (2014) observed similar $\mathrm{R}^{2}$ values ranging from 0.898 to 0.996 for Taro (Colocasia esculenta L. Schott) cultivated in South Africa. Similar $r^{2}(0.86$ and 0.91$)$ were observed by lqbal et al. (2014) and by Jin et al. (2014) for wheat cultivation in China. The intercept represented by (a) of the 1st degree equation indicates the point where the $y$-axis is cut, being indicated in this case by $0.24 ; 0.33 ;-0.46 ;-0.43 ;-0.42$ and 0.38 for $25,50,75,100,125$ and $150 \%$ of ETc, respectively. The regression coefficient represented by (b) of the equation ranged from 0.68 to 0.95 in plots irrigated with $25 \%$ and $125 \%$ of ETc, respectively.

The AquaCrop model is able to simulate the yield of herbaceous crops under various management and environmental conditions, using few conservative parameters and small number of input variables. Vanuytrecht et al. (2014) reported that even though the model has already been tested and applied in several regions, efforts are continually being made to further improve water productivity and use simulations, introducing new concepts and equations into the model without compromising its simple approach and transparency of simulation. Ahmadi et al. (2015) advise that in the next versions of AquaCrop, changes should be made to the basic crop development and growth equations to fill the small gaps of the model. In this sense, Raes et al. (2009) reported the importance of the model to simulate small time intervals, proving to be very useful to study the effect of specific events in a specific parameter. This type of production is essential to understand the responses of crops to environmental changes. Paredes et al. (2014) and Shrestha et al. (2013) confirm the importance of possible changes among irrigation levels, soil water potential and soil water components that affect canopy development, leaf production and senescence.

\section{Materials and methods}

\section{Plant materials}

The AquaCrop model was evaluated with data from an experiment carried out between 11/17/2015 and 02/01/2016, at the Agricultural Sciences Center of the Federal University of Alagoas (CECA / UFAL), located in the municipality of Rio Largo, Alagoas State (AL) ( $9^{\circ} 29$ '45 "S, 35 -49' 54" W and 127 m a.s.I.), Northeastern Brazil. According to Thornthwaite and Matter's classification, the climate of the region is humid and megathermal, with moderate water deficit in the summer and excess water in the winter. The mean annual air temperature is $25.4^{\circ} \mathrm{C}$ and the mean annual precipitation around $1800 \mathrm{~mm}$, with $70 \%$ of rainfall concentrated between April and August (Souza et al., 2005; Ferreira Junior et al., 2014). According to the analysis of the Department of Soil of CECA / UFAL, the soil was characterized as an Argisolic Yellow Latosol, with clayey texture and slope less than $2 \%$ (Table 1 ).

Meteorological data of the experimental period were obtained from the automatic agrometeorological station (Micrologger - 21 CR 1000, Campbell Scienntifc, Logan, Utah) of the Department of Agrarian Sciences, $30 \mathrm{~m}$ away from the experimental area. At 10-minute intervals, the following meteorological elements were measured: air temperature $\left(\mathrm{T},{ }^{\circ} \mathrm{C}\right)$, relative air humidity $(\mathrm{RH}, \%)$, wind speed at $2 \mathrm{~m}$ of height (u2, m s-1) and rainfall $(P, \mathrm{~mm})$. The climate archive was created based on meteorological variables, which in turn served as input for model simulations.

\section{Planting, statistical design and treatments}

The variety of common bean used in the experiment was crioula rosinha, with indeterminate growth habit (type II); erect posture; average cycle of 78 days; average of 34 days for flowering; white flower; green pod, slightly pink in maturation and pigmented pod in harvest (Araújo and Teixeira, 2012). Seeding was performed manually, with three seeds per pit at spacing of $0.50 \mathrm{~m}$ between rows and density of 13 to 15 plants per linear meter, which totaled a final stand of 250,000 plants per hectare. At 15 days after sowing (DAS), pruning was performed, leaving one plant per pit. The total experimental area was $1920 \mathrm{~m}^{2}$.

The experimental design was randomized block with four replicates. Treatments were composed of six levels of irrigation on the basis of crop evapotranspiration (ETC) fractions $(25 \%, 50 \%, 75 \%, 100 \%, 125 \%$ and $150 \%$ of ETC). All treatments received the same irrigation depths in the initial period (15 DAS). Observations and field measurements included the dates of each crop development stage (Table 2), as classified by the FAO56 bulletin (Allen et al., 1998). The time required to start the AquaCrop modeling was defined when $90 \%$ emergence occurred (Raes et al., 2009).

The $\mathrm{Kc}$ recommended by FAO was adopted (Allen et al., 1998), whose values are 1.1 and 1.2 for the vegetative and reproductive phases, respectively, which were then adjusted to the meteorological conditions and crop characteristics during the experimental period. The ETc values were calculated by Equation 1:

$E T \_c=E T \_0 \quad K \_c$

Where; ETO is the reference evapotranspiration estimated by the Penman-Monteith method (Allen et al., 1998).

In the bean crop irrigation, system consisting of microsprinkler with spacing of $2 \times 2.5 \mathrm{~m}$, service pressure of 137.2 $\mathrm{kPa}$, with average flow of $50 \mathrm{~L} \mathrm{~h}-1$ per emitter and application intensity of $5.06 \mathrm{~mm} \mathrm{~h}-1$ was adopted. Soil water content in the root zone (SWC, $\mathrm{mm}$ ) was measured every 10 s and the mean recorded every thirty minutes using Time Domain Reflectometry (TDR), (CS616, Campbell Scientific, 
Logan, Utah) connected to a CR1000 data acquisition system. Probes were vertically positioned in the soil, distant $0.15 \mathrm{~m}$ from plants and within central rows, at 0-0.30 m depth, according to methodology used by Rocha et al. (2014).

\section{AquaCrop description}

For simulation, four input archives were used: 1) climatic archive: minimum and maximum air temperature, ETO, rainfall and $\mathrm{CO}_{2} ; 2$ ) crop archive: time of emergence, maximum canopy coverage, beginning of senescence and maturity; 3 ) irrigation archive and 4) archive with the initial soil water conditions. The water productivity used by the crop (WP) is considered constant for a given climate and crop and can be grouped for C3 crops between 15 and 20 $\mathrm{gm}^{-2}$ and 30 and $35 \mathrm{gm}^{-2}$ for C4 crops (Steduto et al. 2009). The WP parameter in the model is standardized to make the model applicable to various locations and seasons, including future climate simulations (Steduto et al., 2009; Hsiao et al., 2009). Grain yield (GY) is calculated as the product of biomass (B) and harvest index ( $\mathrm{HI}$ ) as shown in equations 2 and 3 . $\mathrm{HI}$ is simulated by a linear increase over time, from flowering to physiological maturation (Steduto et al., 2009):

$$
\begin{aligned}
& \mathrm{GY}=\mathrm{B} H \mathrm{HI} \\
& \mathrm{B}=\mathrm{K} \_\mathrm{SB} \text { WP } \sum\left(\mathrm{T} \_r / E T \_0\right)
\end{aligned}
$$

Where; WP is the water yield $\left(\mathrm{g} \mathrm{m}^{-2}\right)$ adjusted for atmospheric $\mathrm{CO}_{2}$ concentration, synthesized products and soil fertility, Ksb is an adjustment factor for air temperature as a function of degree-days, $\mathrm{Tr}$ is the real crop transpiration and ETO is the reference evapotranspiration (Raes et al., 2009).

\section{AquaCrop calibration and validation}

The AquaCrop model was calibrated for bean crop, taking as reference soybean crop for the conservative parameters of the model, because both belong to the Fabaceae family. Singels et al. (2008) reported that most mechanistic models require a set of data and / or crop parameters, and are divided into three types: ecotypes, varieties and species. However, only parameters of ecotypes and varieties must be adjusted by the model user.

To feed and calibrate the archive with the crop parameters, one linear meter of plants were collected every 10 days for biometric and destructive analyses, where stem, leaves and pods partition was performed. AquaCrop was calibrated for common bean during the dry season (October to March) in the 2015/2016 harvest season using experimental data for $100 \%$ of ETc because it presented conditions with greater expressiveness of the variety yield potential. Then, it was validated with experimental data from the other irrigation depths. Further details on this study are described in Magalhães et al. (2017).

The simulated results of SWC, canopy coverage, biomass and grain yield were compared with results observed in each treatment. For this purpose, input data of the model described in Table 3 were used. Calibrated data were mainly adjusted for biomass and grain yield and then ratified for the soil water content. Likewise, Garcia-Vila et al. (2009) calibrated the AquaCrop model for biomass and then adjusted with crop evapotranspiration (soil water content) and yield for cotton.

\section{Model performance}

The model performance was evaluated based on the root mean square error (RMSE), Willmott's index of agreement (d) (Willmott, 1982), Pearson's correlation coefficient ( $r$ ) and percentage deviation (D), according to the following equations:

$\operatorname{RMSE}=\left[\mathrm{N}^{\wedge}(-1) \sum_{-}(\mathrm{i}=1)^{\wedge} \mathrm{N}\left(\mathrm{s}_{-} \mathrm{i}-\mathrm{o}_{-} \mathrm{i}\right)^{\wedge} 2\right]^{\wedge} 0.5$

$\mathrm{d}=1-\left[\left(\Sigma_{-}(\mathrm{i}=1)^{\wedge} \mathrm{N}\left(\mathrm{S}_{-} \mathrm{i}-\mathrm{O}_{-} \mathrm{i}\right)^{\wedge} 2\right) /\left(\left|\mathrm{S}_{-} \mathrm{i}^{\wedge^{\prime}}\right|+\left|O_{-} \mathrm{i}^{\wedge^{\prime}}\right|\right)^{\wedge} 2\right]$

$r=\left(\Sigma\right.$ [O_i S_i- $\left.\left.\left(\Sigma O_{-} i \quad \Sigma S_{-} i\right) / N\right]\right) / v\left(\left(\Sigma\left[O_{-} i \wedge 2-\left(\sum O_{-} i\right)^{\wedge} 2 / N\right)\right.\right.$

)$\left.\left(\Sigma\left[S_{-} i^{\wedge} 2-\left(\Sigma S_{-} i\right)^{\wedge} 2 / N\right)\right)\right)$

$D=\left(S_{-}(i)-O_{-}(i)\right)^{*} 100 / O_{-} i$

Where; Si and Oi indicates simulated and observed values, respectively; $\mathrm{N}$ is number of observations for all statistical indexes; $\mathrm{Si}^{\prime}$ and $\mathrm{Oi}^{\prime}$ indicates deviations from the average.

The root means square error (RMSE) synthesizes the mean difference between observed and estimated values. The closer the RMSE is to zero, the better the model simulation performance. The concordance index (d) expresses the accuracy of estimated values in relation to those observed. It varies from zero, which indicates null, to 1 , which indicates perfect concordance. The $r$ expresses the degree of linear association between two random variables, that indicates to what extent the values of one variable are related to the values of another variable.

\section{Conclusion}

The model shows good performance between observed and simulated values of soil water content, dry biomass and yield in several water conditions and can assist in decision making and water management in irrigated crops. The AquaCrop model estimates accumulated biomass and grain yield more efficiently in irrigated crops without water restriction.

\section{Acknowledgments}

The authors thank the Coordination of Improvement of Higher Level Personnel (CAPES) for granting doctoral scholarship to the first author.

\section{References}

Aamaas B, Peters GP (2017) The climate impact of Norwegians' travel behavior. Travel Beh Soc. 6:10-18.

Abedinpour M, Sarangi A, Rajput TBS, Man S, Pathak H, Ahmad T (2012) Performance evaluation of AquaCrop model for maize crop in a semi-arid environment. Agri Water Manag. 110:55-66.

Ahmadi, SH, Mosallaeepour E, Kamgar-Haghighi AA, Sepaskhah, AR (2015) Modeling maize yield and soil water content with AquaCrop under full and deficit irrigation managements. Water Resour Manag. 29:2837-2853.

Allen RG, Pereira LS, Raes D, Smith M (1998) Crop evapotranspiration. Guidelines for computing crop water requirements. Irrig and Drainage Paper no 56. Rome: FAO. $300 \mathrm{p}$. 
Andarzian B, Bannayan M, Steduto P, Mazraeh H, Barati M E, Barati M A, Rah-Nama A (2011) Validation and testing of the AquaCrop model under full anddeficit irrigated wheat production in Iran. Agric Water Manag. 100:1-8.

Araújo AP, Teixeira MG (2012) Variabilidade dos Índices de Colheita de Nutrientes em Genótipos de Feijoeiro e Sua Relação com a Produção de Grãos. Rev Bras Cien do Solo. 36:137-146.

Araya A, Solomon H, Kiros M H, Afewerk K, Taddese D (2010) Test of AquaCrop model in simulating biomass and yield of water deficient and irrigated barley (Hordeum vulgare). Agric Water Manage. 97:1838-1846.

Beletse, YG, Laurie R, du Plooy CP, van den Berg A, Laurie S (2011) Calibration and validation of AquaCrop model for orange fleshed sweet potatoes. Capacity development for farm management strategies to improve crop water productivity using AquaCrop: Lessons learned. UNW-DPC Publication Series, Knowledge (7).

Bello ZA, Walker S, Tfwala CM (2011) Predicting Pearl millet response to water under South African climatic conditions. Capacity Development for Farm Management Strategies to Improve Crop Water Productivity Using AquaCrop: Lessons Learned. UNW-DPC Publication Series, Knowledge, (7).

Biazin B, Stroosnijder L (2012) To tie or not to tie ridges for water conservation in Rift Valler drylands of Ethiopia. Soil Tillage Res. 124:83-94.

CONAB - Companhia Nacional de Abastecimento, abril 2017. Acompanhamento de safra brasileira: grãos, 4 - SAFRA 2016/17- N. 7 - Sétimo levantamento.

Darko RO, Shouqi Y, Haofang Y, Liu J, Abbey A (2016) Calibration and validation of AquaCrop for deficit and full irrigation of tomato. Int J Agric Biol Eng. 9:104-110.

Du WY, He XK, Shamaila Z, Hu ZF, Zeng AF (2011) Yield and biomass prediction testing of AquaCrop model for winter wheat. Transactions of the Chinese Society for Agric Mach. 42:174-183. (in Chinese).

Farahani, RZ, Hekmatfar M. (2009) Facility location: Concepts, models, algorithms and case studies. Berlin: Springer.

Ferreira Junior RA, Souza JL, Escobedo JF, Teodoro I, Lyra GB, Araújo Neto RA (2014) Cana de açúcar com irrigação por gotejamento em dois espaçamentos entrelinhas de plantio. Rev Bras Eng Agric Amb. 18:798-804.

Garcia-Vila M, Fereres E, Mateos L, Orgaz F, Steduto P (2009) Deficit irrigation optimization of cotton with AquaCrop. Agron J. 101:477-487.

Geerts S, Raes D, Garcia M, Miranda R, Cusicanqui JA, Taboada C, Mendoza J, Huanca R, Mamani A, Condori O, Mamani J, Morales B, Osco V, Steduto P (2009) Simulating yield response of Quinoa to water availability with AquaCrop. Agron J. 101:499-508.

Jin $X L$, Feng HK, Zhu, XK, Li ZH, Song, SN, Song XY, Yang GJ, XU XG, GUO WS (2014) Assessment of the AquaCrop model for use in simulation of irrigated winter wheat canopy cover, biomass, and grain yield in the North China Plain. PloS One. 9:1-11, e86938.

Gervais $M$, Bullock $P$, Mkhabela $M$, Finlay $G$, Raddatz $R$ (2010) Improvements to the accuracy of modelled soil water content from the second generation Prairie agrometeorological model. Can J Soil Sci. 90:527-542.

Heng L K, Hsiao T C, Evett S, Howell T, Steduto P (2009) Validating the FAO AquaCrop model for irrigated and water deficient field maize. Agron J. 101:488-498.
Homayounfar M, Lai SH, Zomorodian M, Sepaskhah AR, Ganji A (2014) Optimal crop water allocation in case of drought occurrence, imposing deficit irrigation with proportional cutback constraint. Water Resour Manag. 28:3207-3225.

Hsiao TC, Lee H, Pasquale S, Basilio RL, Dirk R, Elias F (2009) AquaCrop - The FAO Crop Model to simulate yield response to water. III. Parameterization and testing for maize. Agron J. 101:448-459.

Hussein F, Janat M, Yakoub A (2011) Simulating cotton yield response to deficit irrigation with the FAO AquaCrop model. Spanish J Agric Res. 9:1319-1330.

Iqbal AM, Shen Y, Stricevic R, Pei H, Sun H, Amiri E, Penas A, Del Rio $S$ (2014) Evaluation of the FAO AquaCrop model for winter wheat on the North China Plain under deficit irrigation from field experiment to regional yield simulation. Agric Water Manage. 135:61-72.

Khoshravesh M, Mostafazadeh-Fard B, Heidarpour M, Kiani AR (2013) AquaCrop model simulation under different irrigation water and nitrogen strategies. Water Sci Technol. 67:232-238.

Kumar P, Sarangi A, Singh D K, Parihar S (2014) Evaluation of AquaCrop model in predicting wheat yield and water productivity under irrigated saline regimes. Irrig Drain. 63:474-487.

Mabhaudhi T, Albert T M, Yacob GB (2014) Parameterization and evaluation of the FAO-AquaCrop model for a South African taro (Colocasia esculenta L. Schott) landrace. Agric For Meteorol. 192:132-139.

Magalhães ID, Lyra GB, Souza JL, Teodoro I, Cavalcante CA, Ferreira Junior RA, Souza RC (2017) Physiology and Grain Yield of Common Beans under Evapotranspirated Water Reposition Levels. Irrig Drain Syst Eng. 6:183-290.

Mathobo R, Marais D, Steyn JM (2017) The effect of drought stress on yield, leaf gaseous exchange andchlorophyll fluorescence of dry beans (Phaseolus vulgaris L.). Agric Water Manag. 180:118-125.

Mebane VJ, Day RL, Hamlett JM, Watson JE, Roth GW (2013) Validating the FAO AquaCrop model for rainfed Maize in Pennsylvania. Agron J. 105:419-427.

Mkhabela MS, Bullock PR (2012) Performance of the FAO AquaCrop model for wheat grain yield and soil moisture simulation in Western Canada. Agric Water Man. 110:1624.

Monteith JL (1977) Climate and the efficiency of crop production in Britain. Phil. Trans R Soc Lond. B. 291: 27729

Nyakudyaa IW, Stroosnijder L (2014) Effect of rooting depth, plant density and planting date on maize (Zea mays L.) yield and water use efficiency in semi-arid Zimbabwe: modelling with AquaCrop. Agric Water Manag 146:280296.

Paredes P, Torres MO (2017) Parameterization of AquaCrop model for vining pea biomass and yield predictions and assessing impacts of irrigation strategies considering various sowing dates. Irrig Sci. 35:27-41

Paredes P, Melo-Abreu JP, Alves I, Pereira LS (2014) Assessing the performance of the FAO AquaCrop model to estimate maize yields and water use under full and deficit irrigation with focus on model parameterization. Agric Water Manag. 144:81-97.

Polón-Pérez $R$, Ruiz-Sánchez $M$, Miranda-Caballero $A$, Ramírez-Arrebato MA (2017) Effects of Water Stress on 
Grain Yield in the Vegetative Phase of bean Cultivation (Phaseolus vulgaris L.). Rev Cien Tec Agrop. 26:66-70.

Raes D, Steduto P, Hsiao TC, Fereres E (2009) AquaCrop - the FAO crop model to simulate yield response to water. II. Main algorithms and software description. Agron J. 101:438-447.

Raes D, Steduto P, Hsiao T C, Fereres E (2011) AquaCrop Reference Manual. FAO, Land and Water Division, Rome, Italy, Available

at

_htttp://www.fao.org/nr/water/docs/aquacrop.html_ (accessed on Mar-07/2013).

Rocha AEQ, Lyra GB, Souza JL, Lyra GB, Medeiros RP, Teodoro I (2014) Conteúdo de água no solo por reflectometria no domínio do tempo e balanço de água no solo em cultivo de milho. IRRIGA. 19:267-278.

Salemi H, Mohd-Soom MA, Lee TS, Mousavi SF, Ganji A (2011) Application of AquaCrop model in deficit irrigation management of Winter wheat in arid region. Afr J Agric Res. 6:2204-2215.

Shrestha N, Raes D, Vanuytrecht E, Sah SK (2013) Cereal yield stabilization in Terai (Nepal) by water and soil fertility management modeling. Agric Water Manag. 122:53-62.

Singels A, Jones M, van der Berg, M (2008) DSSAT v 4.5 Canegro Sugarcane Plant Module. Scientific Documentation. International Consortium for Sugarcane Modelling.

Singh A (2014) Irrigation planning and management through optimization modelling. Water Resour Manag 28:1-14.

Souza JL, Nicácio RM, Moura MAL (2005) Global solar radiation measurements in Maceió, Brasil. Renew Energ. 30:1203-1220.
Souza JVRS, Saad JCC, Sanchez-Roman RM, RodriguezSinobas $L$ (2016) No-till and direct seeding agriculture in irrigated bean: Effect of incorporating crop residues on soil water availability and retention, and yield. Agric Water Manag. 170:58-166.

Steduto P, Hsiao TC, Fereres E (2007) On the conservative behaviour of biomass water productivity. Irrig Sci. 25:189207.

Steduto P, Hsiao T C, Raes D, Fereres E (2009) AquaCrop-The FAO crop model to simulate yield response to water: I. Concepts and underlying principles. Agron J. 101:426-437.

Stricevic R, Cosic M, Djurovic N, Pejic B, Maksimovic L (2011) Assessment of the FAO AquaCrop model in simulation of rainfed and supplementally irrigated maize, sugar beet and sunflower. Agric Water Manag. 98:1615-1621.

Tamagi, JT, Opazo, MAU, Johann, JA, Boas, MAV (2018) Uniformidade de distribuição de água de irrigação por aspersores compensantes e não compensantes em diferentes alturas. IRRIGA, 21:631.

Vanuytrecht E, Raes D, Steduto P, Hsiao TC, Fereres E, Heng LK, Garcia Vila M, Mejias Moreno P (2014) AquaCrop: FAO'S crop water productivity and yield response model. Environ Model Softw. 62:351-360.

Vila MG, Fereres E, Mateos L, Orgaz F, Steduto P (2009) Deficit irrigation optimization of cotton with AquaCrop. Agron J. 101:477-487.

Willmott CJ (1982) Some comments on the evaluation of model performance. Bull Amer Meteor Soc. 63:1309-1313

Zeleke KT, Luckett D, Cowley R (2011) Calibration and testing of the FAO AquaCrop model for canola. Agron J. 103:16101618. 